\title{
Prevalence and etiology of mastitis in traditionally managed camels (Camelus dromedarius) in selected pastoral areas in eastern Ethiopia
}

\author{
Eyassu Seifu* and Bekele Tafesse
}

Department of Animal Sciences, Haramaya University, P. O. Box 138, Dire Dawa, Ethiopia.

\section{Abstract}

Prevalence and causes of mastitis in traditionally managed camels in selected pastoral areas in eastern Ethiopia were assessed. The prevalence of camel mastitis was determined by the California mastitis test (CMT) and by clinical examinations of the udder and milk samples. A total of 642 udder quarters from 161 camels were examined from three locations for the determination of clinical cases and CMT. Among the CMT positive milk samples and milk samples collected from clinical quarters, 174 randomly selected samples were further examined for identification of the etiological agents of camel mastitis. The overall prevalence of mastitis observed in camel herds examined as assessed by the CMT and clinical examinations of the udder or milk (76.0\%) was very high. The high prevalence of mastitis in the camel herds examined could be attributed to the unhygienic milking procedures followed by the camel owners and the poor hygienic condition of the milking area. The bacterial species isolated from the camel milk samples include coagulase negative staphylococci (39.6\%), Streptococcus dysagalactiae (22.2\%), Corynebacteria spp. (9\%), Bacillus spp. (7.6\%), Streptococcus uberis (7.6\%), Escherichia coli (6.3\%), Staphylococcus aureus (4.2\%) and Streptococcus agalactiae (3.5\%). These results suggest that measures need to be taken to improve the health of camels and the quality of camel milk in the study areas.

Keywords: Camel; Causative agent; Mastitis; Prevalence; Udder health.

\section{Introduction}

The one-humped camel (Camelus dromedarius) plays an important role as a primary source of subsistence in the lowlands of Ethiopia. Camels live in arid and semi-arid areas which are not suitable for crop production and where other livestock species hardly thrive. Because of their outstanding performance in the arid and semiarid environments of eastern Ethiopia where browse and water are limited, pastoralists rely mainly on camels for their livelihood. In these areas, camel is mainly kept for milk production and produce milk for a lon- 
ger period of time even during the dry season when milk from cattle is scarce (Bekele Tafesse et al., 2002). Ethiopia possesses over 1 million dromedary camels (FAO, 2002) and the majority of these camels are found in eastern part of the country. The annual camel milk production in Ethiopia is estimated to be 75, 000 tones (Getachew Felleke, 2003).

Mastitis is a complex disease occurring worldwide among dairy animals with heavy economic losses. Mastitis results in milk compositional changes such as increase in leukocyte counts, leakage of plasma proteins into the milk, cell damage resulting in leakage of intracellular constituents into milk, change in ion composition and decrease in milk production (Korhonen and Kaartinen, 1995).

Bacterial infections are considered the primary cause of mastitis in domestic animals. The causative agents of bovine mastitis are well defined but as far as camels are concerned, there is paucity of information about the etiological agents associated with camel mastitis. Few available literatures indicate that Staphylococcus aureus, Streptococcus spp. (Barbour et al., 1985; Abdurahman et al., 1995; Al-Ani and Al-Shareefi, 1997; Younan et al., 2001), Micrococcus spp. (Barbour et al., 1985; Al-Ani and Al-Shareefi, 1997), Streptococcus agalactiae (Abdurahman et al., 1995; Younan et al., 2001), coagulase negative staphylococci (Abdurahman et al., 1995), Staphylococcus epidermides, Pasteurella haemolytica (Al-Ani and Al-Shareefi, 1997), Escherichia coli (Abdurahman et al., 1995; Al-Ani and Al-Shareefi, 1997) and Corynebacterium spp. (Barbour et al., 1985) have been implicated as causes of mastitis in camels.

There is extensive literature on bovine mastitis and to a lesser extent on ovine and caprine mastitis; however, little is known about mastitis in camels. There is limited information on the prevalence and causative agents of camel mastitis in Ethiopia. The prevalence and causes of mastitis differ markedly due to geographical area and individual herd management (Guidry, 1985). To establish an efficient mastitis control program in a dairy herd, baseline information on the nature of mastitis and economic impact of the problem need to be known (Honkanen-Buzalski and Pyörälä, 1995). The principal steps in mastitis control program are to undertake a preliminary mastitis screening survey and to evaluate the udder health status in the herd (Honkanen-Buzalski and Pyörälä, 1995). This study was, therefore, conducted with the objectives to determine the prevalence of mastitis in traditionally managed camels in Jijiga, Shinile and Errer valley and identify the major etiological agents of camel mastitis at the study areas. 


\section{Materials and methods \\ Description of the study area}

This study was conducted in Shinile, Jijiga and Errer valley in eastern part of Ethiopia. The areas are characterized by unreliable and erratic rainfall with a precipitation ranging from 300 to $600 \mathrm{~mm}$ per annum, high ambient temperature $\left(>30^{\circ} \mathrm{C}\right)$, sparsely distributed vegetation dominated by Acacia species, cactus and bushy woodlands (Bekele Tafesse, 2001). These are arid and semi-arid lowlands lying at an altitude of 500-1500 m above sea level and are not suitable for crop production. In these areas, camels are herded by nomadic pastoralists who rely mainly on livestock husbandry for their livelihood.

Survey on prevalence and traditional control methods of mastitis in camels

A single-visit, multiple-subject diagnostic survey (ILCA, 1990) was used to assess the occurrence of mastitis and traditional management practices used to control mastitis in camels. A total of 73 households who own camels and who are familiar with camel husbandry were selected from Jijiga ( $n=31)$, Shinile $(n=32)$ and Errer valley $(n=10)$ using purposive sampling technique. Households at each location were selected based on accessibility of the village and willingness of the camel owners to take part in the interview.

The camels were at different stages and numbers of lactation, and they were of various age groups. Information about traditional management, herd size, milking frequency, milking procedure, occurrence of mastitis, and traditional mastitis control methods was obtained from camel owners by means of a semistructured questionnaire. The camels were fed exclusively on natural browse, watered on the average every 3-4 days, herded during the daytime on communal grazing lands and kept at night in traditional enclosures (Corral) made of thorny bushes and tree branches as protection from predators. The camels were milked on the average three times a day.

Milk sample collection

A total of 642 udder quarters (410 from Jijiga, 72 from Shinile and 160 from Errer valley) were examined and 634 quarter milk samples were aseptically collected from 161 lactating camels and examined for clinical cases and/or subjected to the California mastitis test (CMT). Milk samples were collected from individual quarters during morning milking time. Before milking, all quarters were carefully examined by visual observation and palpation. The teat ends 
were thoroughly washed with water and dried with clean towel. Then teats were disinfected using swabs which were dipped into $70 \%$ ethanol. The first three to four squirts of milk from each quarter were drawn onto a strip cup and examined for the presence of clots, flakes, blood or pus and change in the colour of milk. Approximately two to three $\mathrm{ml}$ of milk from each quarter was drawn onto paddle cups for the CMT test. Then ten $\mathrm{ml}$ of milk was collected from each teat directly into clean and sterile plastic tubes and transported to the laboratory in an icebox for bacteriological examination.

Determination of prevalence

Prevalence of clinical mastitis was determined by visual observation and palpation of the udders in addition to milk samples.

California mastitis test

CMT on camel milk samples was conducted using the method described by Schalm and Noorlander (1957) immediately after collecting the milk samples. Scores represented four categories: 0 , negative $(-)$ or trace $( \pm) ; 1$, positive $(+)$; 2 , positive $(++)$ and 3 , positive $(+++)$. Negative $(-)$ and trace $( \pm)$ reactions were considered as "negatives" and different intensities of positive reactions $(+,++$, +++ ) were considered as "positives".

Bacteriological examinations

Among the CMT positive milk samples (433) and milk samples collected from clinical quarters (47), 174 samples were randomly selected and used for bacteriological analysis. Bacterial isolation and identification were done at the International Livestock Research Institute laboratory (Debre Zeit, Ethiopia) according to standard procedures. Each milk sample $(10 \mu \mathrm{l})$ was streaked onto a plate of blood agar (5\% defibrinated sheep blood) (Oxoid, Hampshire, England). Plates were incubated at $37^{\circ} \mathrm{C}$ for $48 \mathrm{~h}$. The colonies grown were subjected to the following tests as recommended by the National Mastitis Council (NMC, 1987): morphology, haemolysis pattern and Gram stain. Gram-positive cocci were tested for catalase, and catalase-positive isolates further tested with coagulase test. Streptococci were identified by performing CAMP, escilin, hipurate, reffinose, salicin, mannitol, and inulin tests. Gram-negative rods were further differentiated by testing for motility, lactose fermentation (growth on MacConkey agar) and by using oxidase test. 
Statistical analysis

Descriptive statistics was used to analyze the data using the Minitab software version 12.21 (Minitab, 1998).

\section{Results}

The average herd size per household and milking procedure in study area are indicated in Table 1. Variation in milking procedure was observed between the three locations studied (Table 1). In all the three locations, milk ejection was initiated by letting the calves to suckle their dams before milking. Washing the udder/teats of camels is not practiced in all the three locations prior to milking. The majority of camel owners in Shinile areas $(81.3 \%, n=32)$ wash their hands before milking; however, small proportion $(30 \%, \mathrm{n}=10$ ) of the respondents in Errer valley reported that they wash their hands before milking. Half of the respondents in Shinile and Errer valley reported that they wash and smoke milking utensils before milking camels. In Jijiga, the camel owners neither wash milking utensils nor their hands before milking.

Of the 73 households interviewed, the majority of the respondents (96\%) reported that they use traditional medicines to treat camel mastitis. The most common traditional practices used to treat camel mastitis were use of various plant species and branding with hot iron (Table 1). The camel owners use extracts from the roots, leaves, seeds and exudates of different plant species to treat camel mastitis (Table 4).

Camel mastitis is known by different names in the study areas (Table 1). Gofla is the predominant type of camel mastitis in the study areas and it causes a significant decline in milk yield as reported by the respondents. It is a clinical type characterized by swelling of the udder. Arar (Carcar) is a mild type and the second prevalent type of camel mastitis in the areas. It causes swelling of the udder and release of pus from the teats. Jid is the third abundant type of mastitis in camels. It is a chronic form and causes blind teats.

Out of the 161 camels examined, 13 animals (8.1\%) showed clinical cases characterized by swollen, reddened, hot and hardened udder and alteration in the colour and consistency of the milk. Of the 642 quarters examined, eight teats $(1.2 \%)$ were blind. The prevalence of sub-clinical mastitis in camel herds as assessed by the CMT was $67.4 \%$ (Table 2). Out of the total 161 camels examined, 57 (35.4\%) were infested by ticks (Table 1). Among the milk samples subjected 
to bacteriological examination, 144 (82.8\%) yielded mastitis pathogens (Table 3).

Table 1. Herd size (mean \pm SD), milking procedure, tick infestation and traditional control measures of camel mastitis in Jijiga, Shinile and Errer valley

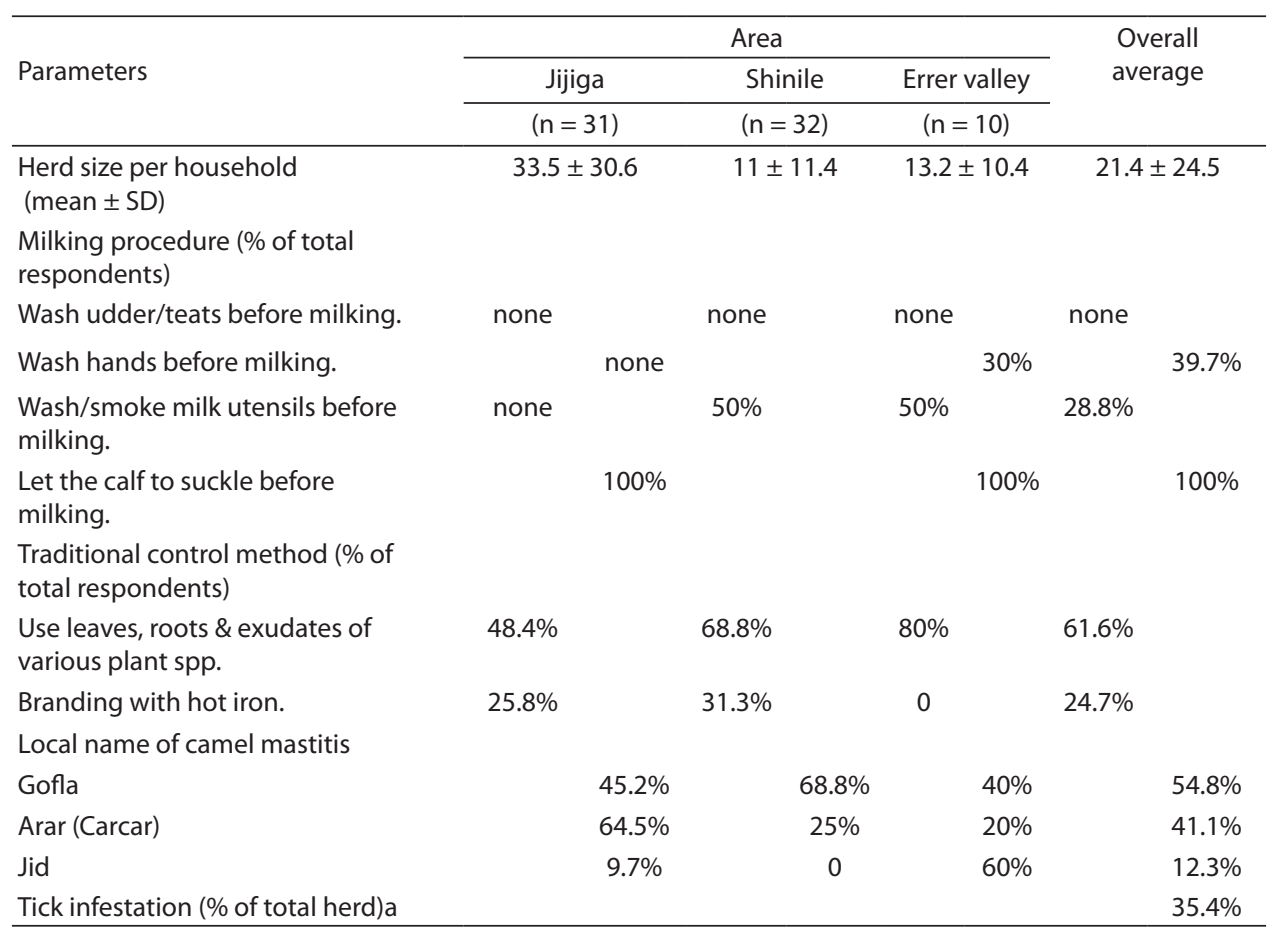

${ }^{a}$ Total number of camels examined were $161 ; \mathrm{n}=$ number of households.

Table 2: California mastitis test (CMT) scores in quarter milk samples and clinical examination of udder quarters of camels in Jijiga, Shinile and Errer valley $(n=642)$

\begin{tabular}{|c|c|c|c|c|c|c|c|c|}
\hline \multicolumn{6}{|l|}{ CMT scores } & \multicolumn{2}{|c|}{$\begin{array}{c}\text { Visual } \\
\text { examination }\end{array}$} & \multirow[t]{2}{*}{$\begin{array}{c}\text { Mastitis } \\
\text { Prevalence }\end{array}$} \\
\hline Area & -ve & Trace & +1 & +2 & +3 & Clinicala & Blind & \\
\hline Jijiga $(n=410)$ & $56(13.7)$ & $39(9.5)$ & $165(40.2)$ & $92(22.4)$ & $27(6.6)$ & $28(6.8)$ & $3(0.73)$ & $76.8 \%$ \\
\hline Shinile $(n=72)$ & $8(11.1)$ & $21(29.2)$ & $21(29.2)$ & $11(15.3)$ & $7(9.7)$ & $2(2.8)$ & $2(2.8)$ & $59.7 \%$ \\
\hline Errer $(n=160)$ & $4(2.5)$ & $26(16.3)$ & $45(28.1)$ & $48(30)$ & 17 (10.6) & 17 (10.6) & $3(1.9)$ & $81.3 \%$ \\
\hline Average $(n=642)$ & $68(10.6)$ & $86(13.4)$ & $231(35.9)$ & $151(23.5)$ & $51(7.9)$ & $47(7.3)$ & $8(1.2)$ & $76.0 \%$ \\
\hline
\end{tabular}


Table 3. Bacterial species isolated from quarter milk samples $(n=174)$ obtained from traditionally managed camels in Jijiga, Shinile and Errer valley

\begin{tabular}{lcc}
\hline Bacterial species & Number of isolates & \% of total isolates \\
\hline Coagulase negative staphylococci & 57 & 39.6 \\
Streptococcus dysagalactiae & 32 & 22.2 \\
Corynebacteria spp. & 13 & 9.0 \\
Bacillus spp. & 11 & 7.6 \\
Streptococcus uberis & 11 & 7.6 \\
Escherichia coli & 9 & 6.3 \\
Staphylococcus aureus & 6 & 4.2 \\
Streptococcus agalactiae & 5 & 3.5 \\
Total & 144 & 100 \\
\hline
\end{tabular}

Table 4. Major plant species traditionally used to treat camel mastitis in Jijiga, Shinile and Errer valley

\begin{tabular}{lccc}
\hline Vernacular name (Somali) & Category & Scientific name & Part of plant used \\
\hline Qalaan & shrub & Cadaba rotundifolia & Leaf \\
Aday (Caday) & shrub & Salvadora persica & Leaf and root \\
Dhamajo & tree & Crotolaria albicallis & Exudate \\
Malmaal & tree & Boswellia spp. & Exudate (Resin) \\
Shifu & herb & Trigonella foenum & Seed \\
Irgin & shrub & Euphorbia tirucalli & Exudate \\
Je'ee (jei, jiic) & shrub & Maerua angolensis & Leaf and root \\
\hline
\end{tabular}

\section{Discussion}

The overall prevalence $(76.0 \%)$ of mastitis in camel herds as determined by the CMT and clinical examinations of the udder and the milk samples is higher than that reported by Obied et al. (1996) who found an overall mastitis prevalence of $66.8 \%$ in Sudanese camel herds. However, the present finding is consistent with the findings of Woubit Salah et al. (2001) who reported high prevalence of mastitis in dromedary camels in Borena areas of southern Ethiopia. The apparently high prevalence of mastitis in the camel herds examined might be attributed to the high tick infestation rate. The infested udders (98.3\%) had one or more CMT positive quarters. Tick infestation can predispose camel udders to bacterial infection (Abdurahman, 1996; Obied et al., 1996).

Environmental factors play significant role in the prevalence of sub-clinical (Sandholm, 1995) and clinical (Honkanen-Buzalski and Pyörälä, 1995) mastitis 
in dairy animals. The high prevalence of mastitis observed in the camel herds examined in the present study could be associated with the enclosures where the camels were kept overnight. Camels were kept overnight in an open Corral made of thorny bushes and tree branches which might have contributed to udder injuries and predisposed the udder to infection by environmental pathogens causing mastitis. An injury to the udder causing tissue damage may be reflected in a considerable increase in somatic cell counts in milk (Saloniemi, 1995). Moreover, the unhygienic milking procedure (Table 1) and the generally poor management practiced in the study area might also have contributed to the high prevalence of mastitis in the camel herds examined.

The high percentage of mastitis pathogens isolated from camel milk samples examined in the present study is consistent with the findings of Woubit Salah et al. (2001) who reported that $74 \%$ of the CMT positive quarter milk samples of camels in Borena area of southern Ethiopia yielded pathogenic bacteria. Gram-positive cocci were the main cause of mastitis in the camels and constituted $93.8 \%$ of the total isolates. This finding is in line with that reported by Obied et al. (1996) and Woubit Salah et al. (2001). Among the bacterial isolates, coagulase negative staphylococci (CNS) were identified as the predominant mastitis causing organisms in the camels studied. This agrees with the report of Abdurahman (1996) who found that CNS and Staphylococcus aureus represented $61.1 \%$ and $38.9 \%$, respectively of the total isolates and considered as the main organisms that cause mastitis in the Bactrian camel. Streptococcus dysagalactiae was the second most common cause of mastitis in the camel herds examined in this study. This finding agrees with that reported previously by other researchers (Abdurahman, 1996; Woubit Salah et al., 2001; Guliye et al., 2002). Streptococcus agalactiae and Staphylococcus aureus were reported to be the most common causes of camel mastitis in eastern Sudan (Obied et al., 1996) and Kenya (Younan et al., 2001).

The bacteria isolated from camel milk samples in the present study are types that cause both contagious and environmental mastitis. Correct and good milking techniques are essential in the prevention of both environmental and contagious mastitis. The teats must be cleaned with individual clothes dipped in hot water. The fact that the pathogens isolated from camel milk samples in the present study are bacteria that cause both environmental and contagious mastitis suggest that proper management and adequate hygienic condition of the environment (enclosures) are required in order to minimize occurrence of mastitis in the study area. 
Pastoralists use various traditional (ethno-veterinary) practices to treat sick camels (Bornstein, 1993; Hussein, 1993). The different plant species traditionally used to treat camel mastitis in the study area would be of paramount importance in the future to develop modern drugs which could be used to treat mastitis in camels. Thus, detailed scientific study needs to be conducted on these plant species to determine their potential medicinal properties.

\section{Conclusion}

This study revealed high prevalence of mastitis in camel herds in the study areas. The high prevalence of mastitis was attributed to inadequate hygienic condition of the dairy environment and tick infestation. Thus, good management practices with proper sanitation and tick control measures are required to prevent the incidence of mammary infection in camels in the study areas. The predominant etiological agents of camel mastitis in the study area were found to be coagulase negative staphylococci. The isolation of genera of pathogenic bacteria from the camel milk samples suggests the need for strict hygienic measures during the production and handling of camel milk to reduce public health hazards. Education of the camel owners about the importance of hygienic milking practices would minimize the adverse effect of mastitis on the yield and quality of camel milk.

\section{Acknowledgements}

This study was funded by the Ethiopian Institute of Agricultural Research (EIAR) through the National Camel Research Program.

\section{References}

Abdurahman, O. A. Sh., 1996. The detection of subclinical mastitis in the Bactrian camel (Camelus bactrianus) by somatic cell count and California mastitis test. Vet. Res. Commun., 20, 9-14.

Abdurahman, O. A. Sh., Agab, H., Abbas, B. and Åström, G., 1995. Relations between udder infection and somatic cells in camel (Camelus dromedarius) milk. Acta Vet. Scand., 36, 423-431.

Al-Ani, F. K. and Al-Shareefi, M. R., 1997. Studies on mastitis in lactating one-humped camels (Camelus dromedarius) in Iraq. J. Camel Pract. Res., 4, 47-49. 
Barbour, E. K., Nabbut, N. H., Frerichs, W. M., Al-Nakhli, H. M. and Al-Mukayel, A. A., 1985. Mastitis in Camelus dromedarius in Saudi Arabia. Trop. Anim. Hlth. Prod., 17, 173-179.

Bornstein, S., 1993. Camel health and disease: veterinary projects. In: Hjort af Ornäs, A. (Ed.), The multipurpose camel: interdisciplinary studies on pastoral production in Somalia. Environmental Policy and Society (EPOS), Uppsala, Sweden, pp. 189205.

FAO, 2002. Production Yearbook, Vol. 56, Food and Agriculture Organization of the United Nations, Rome, Italy.

Felleke, G., 2003. A Review of the Small Scale Dairy Sector - Ethiopia. FAO Prevention of Food Losses Programme: Milk and Dairy Products, Post-harvest Losses and Food Safety in Sub-Saharan Africa and the Near East. (http://www.fao.org/ag/ againfo/projects/en/pfl/documents.html) (Accessed on March 11, 2006).

Guidry, A. J., 1985. Mastitis and the immune system of the mammary gland. In: Larson, B. L. (Ed.), Lactation. The lowa State University Press, lowa, pp. 229-262.

Honkanen-Buzalski, T. and Pyörälä, S., 1995. Monitoring and management of udder health at the farm. In: Sandholm, M., Honkanen-Buzalski, T., Kaartinen, L. and Pyörälä, S. (Eds.), The bovine udder and mastitis. University of Helsinki, Finland, pp. 252-260.

Hussein, M. A., 1993. Traditional practices of camel husbandry and management in Somalia. In: Hjort af Ornäs, A. (Ed.), The multipurpose camel: interdisciplinary studies on pastoral production in Somalia. Environmental Policy and Society (EPOS), Uppsala, Sweden, pp. 123-140.

ILCA, 1990. Livestock systems research manual. ILCA Working Paper 1. International Livestock Centre for Africa, Addis Ababa, Ethiopia.

Korhonen, H. and Kaartinen, L., 1995. Changes in the composition of milk induced by mastits. In: Sandholm, M., Honkanen-Buzalski, T., Kaartinen, L. and Pyörälä, S. (Eds.), The bovine udder and mastitis. University of Helsinki, Finland, pp. 76-82.

Minitab, 1998. Minitab for Windows. Release 12.21. Minitab Inc., Drive State College.

NMC, 1987. Laboratory and field handbook on bovine mastitis. National Mastitis Council (NMC) Inc., Madison. 
Obied, A. I., Bagadi, O. and Mukhtar, M. M., 1996. Mastitis in Camelus dromedarius and the somatic cell content of camel's milk. Res. Vet. Sci., 61, 55-58.

Sandholm, M., 1995. A critical view on antibacterial mastitis therapy. In: Sandholm, M., Honkanen-Buzalski, T., Kaartinen, L. and Pyörälä, S. (Eds.), The bovine udder and mastitis. University of Helsinki, Finland, pp. 169-186.

Saloniemi, H., 1995. Use of somatic cell count in udder health work. In: Sandholm, M., Honkanen-Buzalski, T., Kaartinen, L. and Pyörälä, S. (Eds.), The bovine udder and mastitis. University of Helsinki, Finland, pp. 105-110.

Schalm, O. W. and Noorlander, D. O., 1957. Experiments and observations leading to the development of California mastitis test. J. Am. Vet. Med. Asso., 130, 199-204.

Tafesse B., 2001. Studies on Cephalopina titillator, the case of 'Senegal' in camels (Camelus dromedarius) in semi-arid areas of Somali state, Ethiopia. Trop. Anim. HIth. Prod., 33, 489-500.

Tafesse, B., Mekuriaw, Z. and Baars, R. M. T., 2002. Milk production performance of the one humped camel (Camelus dromedarius) under pastoral management in semi-arid eastern Ethiopia. Liv. Prod. Sci., 76, 37-44.

Younan, M., Ali, Z., Bornstein, S. and Müller, W., 2001. Application of the California mastitis test in the intramammary Streptococcus agalactiae and Staphylococcus aureus infections of camels (Camelus dromedarius) in Kenya. Prev. Vet. Med., 51, 307-316.

Woubit, S., Bayleyegn, M., Bonnet, P. and Jean-Baptiste, S., 2001. Camel (Camelus dromedarius) mastitis in Borena lowland pastoral areas, southwestern Ethiopia. Revue Élev. Méd. vet. Pays trop., 54 (3-4), 207-212. 